\title{
Chocolate's Blooming Phenomenon: A Brief Review of The Formation Process and Its Influencing Factors
}

\author{
Rossi Indiarto $^{1}$, Devia Nurul Inayah ${ }^{2}$, Wulansari ${ }^{3}$, Abbya Pratiwi Ramadhani ${ }^{4}$, Vira Putri Yarlina ${ }^{5}$, Aldila \\ Din Pangawikan' \\ Department of Food Industrial Technology, Faculty of Agro-Industrial Technology, Universitas Padjadjaran, \\ Jl. Raya Bandung-Sumedang Km. 21, Jatinangor, Sumedang, 45363, Indonesia \\ ${ }^{1}$ rossi.indiarto@unpad.ac.id; ${ }^{2}$ devia17001@mail.unpad.ac.id; ${ }^{3}$ wulansari17001@ mail.unpad.ac.id; \\ 4abbya17001@mail.unpad.ac.id; ${ }^{5}$ vira.putri.yarlina@unpad.ac.id; ${ }^{3}$ pangawikan@unpad.ac.id
}

\begin{abstract}
One of the indications of chocolate product degradation is blooming. It is distinguished by the loss of surface shine, which is replaced by a white coating. These effects are caused by insufficient processing, inappropriate chocolate content, and incompatible storage conditions. It can alter these characteristics to enhance chocolate's resistance to blooming and its texture, flavor, and appearance. Several factors must be considered when creating blooming-resistant chocolate, such as chocolate particle size, fat content, processing techniques, and storage conditions. This concise review will discuss fat blooming in chocolate, from its formation to its contributing factors and methods for resolving it.
\end{abstract}

Key words: Blooming, fat, defect, organoleptic, perception, physicochemical

\section{INTRODUCTION}

Chocolate is a trendy processed food made from cocoa beans that contain a distinctive taste and high functional compounds, especially a source of antioxidants [1], [2]. It is a confectionery manufactured with cocoa powder and sugar dissolved in cocoa butter [3], [4]. It has a specific flavor, frequently used to produce bread, cakes, and ice cream [5]. Chocolate is divided into two types: real chocolate (couverture) and compound chocolate. Real chocolate contains cocoa liquor and cocoa butter, whereas compound chocolate has cocoa powder and cocoa butter substitutes. Real chocolate is more costly than compound chocolate.

Cocoa butter is a fat found naturally in the cocoa bean. Cocoa butter's physicochemical characteristics result from the presence of triacylglycerols (TAG). Cocoa butter acts as a dispersion medium during the chocolate-making process and thereby establishes a stable crystallinity. It raises the melting point of chocolate, allowing it to remain solid at room temperature. It can also improve the texture and flavor of chocolate bars. A phenomenon known as polymorphism occurs when cocoa butter crystallizes into different crystals in chocolate bars. Multiple types of crystals formed during the manufacturing determine the melting point and texture of the chocolate. As cocoa butter is a costly ingredient in chocolates, several studies have used substitute ingredients known as cocoa butter alternative oils [6]. The most widely used replacement fats for chocolate and coatings are cocoa butter equivalents and cocoa butter substitutes [7].

Chocolate may be damaged in two ways: fat bloom and sugar bloom, both of which cause the chocolate to lose its shine and become coated in a white coating. Fat bloom arises because of poor chocolate storage. Chocolate's physical flaws make it less appealing to customers [8]. Fat bloom is caused by three major factors: composition, processing, and storage conditions [9].

There are several methods for preventing or suppressing the formation of this bloom in chocolate products. By examining and addressing the variables that contribute to blooming in chocolate, it is possible to create chocolate resistant to blooming for an extended period while simultaneously enhancing other chocolate characteristics. As a result, this article is important to discussing blooming in chocolate and the factors causes and solutions for dealing with it. This information can be used to prevent chocolate from blooming, which degrades its quality.

\section{CHOCOLATE BLOOMING AND ITS CAUSES}

Fat bloom is a physical property of chocolate that gives the surface an appearance of a whitish color. Chocolate cannot withstand high temperatures during storage because of the re-crystallization of cocoa butter [10]. Fat bloom occurs when small crystals grow on the surface and within the product after some time [10], [11]. Due to temperature oscillations during storage, fat crystals transform, resulting in new polymorphic forms [12].

Chocolate's surface is more sensitive to temperature changes than its interior. The quantity of liquid fat pressed onto the chocolate's surface can be increased by raising the temperature. A late temperature drop does not cause all of the melted fat to crystallize, but one portion remains liquid in the 
Rossi Indiarto et al., International Journal of Emerging Trends in Engineering Research, 9(8), August 2021, 1156 - 1161

chocolate. Furthermore, the surface of the chocolate becomes porous, allowing the liquid to propagate to the surface of the chocolate, where it crystallizes under certain conditions. Chocolate that has been adequately packaged is more resistant to fat bloom than chocolate that has been improperly packaged [9]. Fat blooms can occur even when production meets all of the requirements for preventing them. It is due to poor storage conditions. When the temperature rises above 32 ${ }^{\circ} \mathrm{C}$, some of the cocoa butter melts.

According to Delbaere et al. [13] and Zhao et al. [14], several factors contribute to blooms in chocolate products, including the 1) tempering method, 2) the composition, 3) the storage temperature, and 4) the microstructure of the chocolate. However, the tempering process is typically carried out correctly during the chocolate production process, ensuring that the chocolate remains stable at $12-18^{\circ} \mathrm{C}$ storage temperature. The second factor is controllable during the production process. In contrast, the third factor is a variable that can be modified during storage. Additionally, because particle size and packaging are more challenging to control and understand, chocolate microstructure influenced by particle size, is critical for controlling fat blooms on the chocolate surface. Several researches have been carried to determine what causes chocolate fat blooms. Additionally, the effect of several ingredient indicators on the formation of fat blooms was examined. Numerous factors contribute to the formation of blooms in chocolate products, as shown in Table 1.

\subsection{Chocolate particle size}

In chocolate, a better understanding of microstructure, influenced by particle size distribution [13], [15], [16]. Thus, a better understanding of the chocolate microstructure, influenced by the particle size distribution, is essential for regulating fat bloom formation [13]. According to Afoakwa et al. [10], fat bloom happens within 24 hours of storage due to liquid and unstable fat on the surface. After 96 hours, the white crystalline structure spreads throughout the chocolate. Small particle size $(18 \mu \mathrm{m})$ had the slowest fat bloom growth rate, while the largest particles size $(50 \mu \mathrm{m})$ had the fastest fat bloom growth rate. Zhao et al. [14] found that samples with small particle sizes are more resistant to fat migration and have fewer white color changes on the surface, resulting in slower fat bloom formation. In contrast, the $15 \mu \mathrm{m}$ sample exhibited a greater oil migration rate and fat bloom development on the surface than the $22 \mu \mathrm{m}$ and $40 \mu \mathrm{m}$ samples kept at $23^{\circ} \mathrm{C}$ [17].

\subsection{Fat replacement}

Adding fat substitutes also prevent the growth of chocolate fat bloom. It can create chocolate with alternative fats to enhance its softness, availability and reduce susceptibility to fat bloom [18]. The chocolate made with different ratios of cocoa butter substitute (CBS) and cocoa butter equivalent (CBE) was stored at $20^{\circ} \mathrm{C}$ for 100 days, with no growing fat blooms. The fat blooms more easily and quickly in certain mixtures of cocoa butter, CBS, CBE, and milk fat. Due to the instability of the crystal network, the TAG becomes mobile, and the liquid phase content rises, causing fat separation and re-crystallization.

Additionally, it can prevent blooms by substituting cocoa butter for coconut and palm oils [6]. To avoid fat bloom, the optimal substitution ratio for chocolate bars made with substituted oil is $20-40 \%$, but $100 \%$ substitution is possible. Still, fat crystallization may take longer, and It may be necessary to chill chocolates below $12{ }^{\circ} \mathrm{C}$ to keep them stable for a long time. The maximum amount of fat substitution needed to maintain the texture of a chocolate bar is $60 \% \mathrm{wt}$ [6]. Moreover, substituting cocoa butter with $4.5 \%$ coconut oil enhances the chocolate's looks and ability to resist bloom development [19]. Likewise, it is believed that adding fats high in lauric fatty acids will result in a more stable chocolate product during crystallization [20]. CBE is also a source of fats and oils compatible with cocoa butter's physical and sensory properties [21]. According to Bahari \& Akoh [18], Illipe butter can help prevent fat blooms in chocolate.

According to Zarringhalami et al. [22], chocolate containing 5\% and $10 \%$ interesterified tea seed oil had a more similar texture to cocoa butter chocolate. The solid fat content (SFC) analysis results indicated that incorporating $10 \%$ interesterified tea seed oil into the chocolate formulation did not affect the cocoa butter melting point. By including $10 \%$ interesterified tea seed oil in chocolate formulations, it is possible to reduce fat bloom formation while maintaining the desired sensory quality of chocolate samples. According to Sonwai and Rousseau [12], demonstrated that milk fat acted as a preservative, preventing the formation of blooms, but only at concentrations greater than $2.5 \%$ of the final product. It found the addition of 5\% milkfat to chocolate to preserve its sensory properties and resistance to temperature cycles [12], [23]. In contrast, Wang et al. [20] studied where the addition of milkfat or cocoa butter can accelerate blooms. Combining these two types of fats can delay bloom formation.

Frazier and Hartel [24] explained that whenever the dough contained an adequate amount of fat, all fats except cacao butter inhibited the formation of fat blooms. Palm and olive oils both exhibit a minimum fat migration rate of $16 \%$, which is required to prevent blooming. At the same time, crystal memory does not affect preventing chocolate chips from blooming. Oil migration is the primary cause of blooms on chocolate chips baked in cookies.

Meanwhile, according to Rosales et al. [25], all crystal promoters significantly inhibited fat bloom formation in chocolate. Chocolate containing $0.25 \% \mathrm{CP} 1$ (mono- and polyglycerol esters derived from high oleic sunflower oil) developed fat blooms more rapidly. It compared chocolate containing $0.25 \% \mathrm{CP} 2$ (a mixture of mono-diglycerides, lecithin, citric acid, and esters from canola oils and palm stearin) and CP3 (canola oil triglycerides previously treated with full hydrogenation). The Buscato et al.[26] studied at a concentration of $0.5 \%$, the inhibitor sorbitan tristearate (STS) inhibited the development of fat blooms. It stated that products stored at $20^{\circ} \mathrm{C}$ did not generate fat bloom when added sorbitan monostearate and cocoa butter stearin were. 
Rossi Indiarto et al., International Journal of Emerging Trends in Engineering Research, 9(8), August 2021, 1156 - 1161

Cocoa butter stearin $(6.0 \%)$ and sorbitan monostearate $(0.15 \%)$ significantly delayed fat bloom generation by 45 and 15 days, respectively.

Fat bloom caused by oil migration is the primary quality issue for chocolate producers because it reduces shelf life and exportability. A molecular diffusion model accurately described liquid oil migration through chocolate. Oil migration mechanisms can be influenced by processing conditions, composition, and possible interactions between these factors [27]. In dark chocolate composites containing up to $7.5 \%$ cocoa butter, the presence of diacylglycerol (DAG) did not delay the emergence of oil migration or prevent fat bloom [28].

\subsection{Processing treatment}

According to Svanberg et al. [29], the two pre-crystallization processes generate structures with significantly different storage stabilities. Compared to the conventional tempering process, well-tempered $\beta$-VI has an excellent and homogeneous structure in solid chocolate, which is ideal for inhibiting fat bloom and migration. However, an excessive structural density results in heterogeneity and a diminished capacity to resist bloom growth. The less-dense the structure, the more resistant it is to moisture migration.

Numerous studies have demonstrated that specific sugar particles can inhibit blooming. Microstructure changes in chocolate can affect blooms due to interactions between emulsifiers, sugars, and fats [13]. Jin and Hartel [30] investigated the effect of particulates on fat blooming in chocolate using a model system made up of half non-fat particles and half cocoa butter, with cocoa powder replaced with sugar particles. Lecithin has been shown to significantly reduce bloom due to its effect on sugar, emulsifier, and fat interactions. The type of particles used in chocolate and coated with lecithin can significantly impact bloom formation during storage. Sweeteners such as maltitol and tagatose can also help prevent blooming in chocolate bars. According to Son et al. [31], when one combined chocolate with tagatose, blooming development was significantly decreased compared to when maltitol was used. In terms of bloom resistance, maltitol outperformed the chocolate group with added sugar. As a result, alternative sweeteners such as tagatose and maltitol improve the final chocolate product's storage stability while also providing anti-blooming properties and health benefits. Rodriguez Furlán et al. [32] examined the use and combination of sucralose $(\mathrm{Su})$ and stevia $(\mathrm{St})$ sweeteners in white chocolate products. As a result, the formation of fat blooms and sugars is increased in products treated $100 \% \mathrm{Su}$ or $50 \% \mathrm{~S}+50 \% \mathrm{Su}$. While products with $50 \% \mathrm{St}+50 \% \mathrm{Su}$ and $75 \% \mathrm{St}+25 \% \mathrm{Su}$ produced less fat bloom, the dense microstructures remained stable.

Fat bloom can be caused by various factors, including inappropriate tempering, inadequate cooling, the addition of fats that are incompatible with cocoa butter, or improperly stored [33]. It may use re-tempering chocolate to avoid the formation of fat blooms. Machálková et al. [34] demonstrate that re-tempering technology can effectively increase chocolate products' resistance to fat bloom, as indicated by increased color stability.

Additionally, Zhao et al. [14] investigated blooming on untempered chocolate, demonstrating a honeycomb-like brown surface with black spots surrounded by white sand flowers after 25 days of room temperature storage. This polymorphic transformation occurs when form IV cocoa butter transforms into form $\mathrm{V}$ crystals. When blooming occurs, the surface whiteness of the non-fat particles increases, but the particle size distribution exhibits a limited white color change effect. Kinta and Hartel [35] investigated the relationship between insufficient tempering and the yield of cocoa beans produced by chocolate during blooming formation. The results indicated that increasing the number of cocoa beans formed more $\beta$ crystals, and the crystallization temperature increased. It means that crystallization takes place earlier.

\subsection{Chocolate storage conditions}

Zhao and James [36] investigated blooms in chocolate at temperatures ranging from 20 to $29^{\circ} \mathrm{C}$ and 20 to $32{ }^{\circ} \mathrm{C}$. The results indicate that melt-mediated polymorphism occurs during temperature cycling. Under a $20-29{ }^{\circ} \mathrm{C}$ cycle, fat crystals form on the chocolate surface. Meanwhile, the chocolate surface becomes roughened during the $20-32^{\circ} \mathrm{C}$ cycle, resulting in variations in the appearance of blooms. Additionally, the liquid fat content is higher at $32{ }^{\circ} \mathrm{C}$ than at $29{ }^{\circ} \mathrm{C}$, resulting in a faster bloom formation. The sensory quality of chocolate deteriorated during storage at 35 degrees Celsius, with visible signs of blooming on the first day of storage. Consumers find the appearance of chocolate unacceptable after a week's storage [37].

Chocolate storage at $30{ }^{\circ} \mathrm{C}$ is unsuitable for short-term storage-generally, a storage temperature of $20^{\circ} \mathrm{C}$ results in good color and texture, however, not in terms of his sensory evaluation. Products that have been tempered are resistant to fat bloom. Even after ten weeks from the production date, the product's texture stored at $6{ }^{\circ} \mathrm{C}$ can be preserved and retains its original attributes. It should keep chocolate products at 12 ${ }^{\circ} \mathrm{C}$ [38]. Table 1 summarizes the various causes of chocolate fat bloom.

Table 1. Contributing factors to chocolate fat bloom and efforts to prevent

\begin{tabular}{lll}
\hline \hline $\begin{array}{l}\text { Influential } \\
\text { factor }\end{array}$ & Findings & Ref. \\
\hline $\begin{array}{l}\text { Chocolate } \\
\text { particle size }\end{array}$ & $\begin{array}{l}\text { When compared to small particles, } \\
\text { products with large particle sizes exhibit } \\
\text { the fastest rate of bloom growth }\end{array}$ & {$[14]$,} \\
\hline $\begin{array}{l}\text { Fat } \\
\text { replacement }\end{array}$ & $\begin{array}{l}\text { The fat alternative can enhance the } \\
\text { softness and resistance to the bloom of } \\
\text { chocolate }\end{array}$ & {$[18]$} \\
\hline $\begin{array}{l}\text { Fat } \\
\text { replacement }\end{array}$ & $\begin{array}{l}\text { Substituting coconut oil or palm oil for } \\
\text { cocoa butter can help reduce the } \\
\text { occurrence of blooms in chocolate, with } \\
\text { a maximum fat substitution of 60\% }\end{array}$ & {$[6]$} \\
\hline
\end{tabular}


Rossi Indiarto et al., International Journal of Emerging Trends in Engineering Research, 9(8), August 2021, 1156 - 1161

\begin{tabular}{|c|c|c|}
\hline $\begin{array}{l}\text { Influential } \\
\text { factor }\end{array}$ & Findings & Ref. \\
\hline $\begin{array}{l}\text { Fat } \\
\text { replacement }\end{array}$ & $\begin{array}{l}\text { By substituting coconut oil for cocoa } \\
\text { butter, it can minimize bloom formation }\end{array}$ & [19] \\
\hline $\begin{array}{l}\text { Fat } \\
\text { replacement }\end{array}$ & $\begin{array}{l}\text { The addition of lauric acid-rich fat can } \\
\text { result in a more stable chocolate product } \\
\text { during crystallization }\end{array}$ & [40] \\
\hline $\begin{array}{l}\text { Fat } \\
\text { replacement }\end{array}$ & $\begin{array}{l}\text { Chocolate formulations containing the } \\
\text { illipe butter and palm-mid fractionation } \\
\text { can help prevent dark chocolate fat } \\
\text { blooms }\end{array}$ & [41] \\
\hline $\begin{array}{l}\text { Fat } \\
\text { replacement }\end{array}$ & $\begin{array}{l}\text { By incorporating interesterified tea seed } \\
\text { oil into chocolate, it can reduce fat } \\
\text { blooms without impairing sensory or } \\
\text { crystallization properties }\end{array}$ & [22] \\
\hline $\begin{array}{l}\text { Fat } \\
\text { replacement }\end{array}$ & $\begin{array}{l}\text { The addition of milk fat can help } \\
\text { prevent fat bloom. }\end{array}$ & $\begin{array}{l}{[12],} \\
{[23]}\end{array}$ \\
\hline $\begin{array}{l}\text { Fat } \\
\text { replacement }\end{array}$ & $\begin{array}{l}\text { Without a combination of the two, } \\
\text { adding milk fat or cocoa butter can } \\
\text { accelerate blooming }\end{array}$ & [20] \\
\hline $\begin{array}{l}\text { Fat } \\
\text { replacement }\end{array}$ & $\begin{array}{l}\text { When compared to other fats, cocoa } \\
\text { butter can inhibit the growth of fat } \\
\text { bloom in chocolate. }\end{array}$ & [24] \\
\hline $\begin{array}{l}\text { Fat } \\
\text { replacement }\end{array}$ & $\begin{array}{l}\text { When mango kernel fat is used as a fat } \\
\text { replacer in chocolate products, it can } \\
\text { inhibit the growth of fat bloom ( } 45 \text { days) } \\
\text { when cocoa fat is used ( } 15 \text { days) during } \\
\text { storage }\end{array}$ & [42] \\
\hline $\begin{array}{l}\text { Fat } \\
\text { replac }\end{array}$ & $\begin{array}{l}\text { The addition of oil-based additives to } \\
\text { chocolate can significantly inhibit the } \\
\text { growth of fat blooms. }\end{array}$ & [25] \\
\hline $\begin{array}{l}\text { Fat } \\
\text { repla }\end{array}$ & $\begin{array}{l}\text { Chocolate products containing } 6.0 \% \\
\text { w/w cocoa butter stearin and } 0.15 \% \\
\text { w/w sorbitan monostearate can delay fat } \\
\text { blooms by } 15-45 \text { days }\end{array}$ & [26] \\
\hline $\begin{array}{l}\text { Fat } \\
\text { replacement }\end{array}$ & $\begin{array}{l}\text { Chocolate products containing } 7.5 \% \\
\text { DAG cocoa butter can prevent oil } \\
\text { migration caused by a fat bloom }\end{array}$ & [38] \\
\hline $\begin{array}{l}\text { Processing } \\
\text { treatment }\end{array}$ & $\begin{array}{l}\text { Compared to conventional tempering, } \\
\text { the Well-tempered } \beta \text {-VI } \\
\text { pre-crystallization stage inhibited fat } \\
\text { bloom and migration. }\end{array}$ & [29] \\
\hline $\begin{array}{l}\text { Processing } \\
\text { treatment }\end{array}$ & $\begin{array}{l}\text { Using a portable NIR spectrometer in } \\
\text { conjunction with a chemometric device, } \\
\text { different temperatures can cause } \\
\text { changes in the shape of fat polymorphs, } \\
\text { resulting in the appearance of fat blooms }\end{array}$ & [43] \\
\hline $\begin{array}{l}\text { Processing } \\
\text { treatment }\end{array}$ & $\begin{array}{l}\text { The use of corn syrup solids (CSS) } \\
\text { sweeteners by } 75 \% \text { and } 50 \% \text { can reduce } \\
\text { chocolate bloom. Lecithin combined } \\
\text { with sucrose, maltitol, corn syrup solids, } \\
\text { and polydextrose sweeteners can } \\
\text { significantly reduce the bloom rate in } \\
\text { chocolate }\end{array}$ & [30] \\
\hline $\begin{array}{l}\text { Processing } \\
\text { treatment }\end{array}$ & $\begin{array}{l}\text { It is possible to keep chocolate products } \\
\text { from blooming by adding maltitol and }\end{array}$ & [31] \\
\hline
\end{tabular}

\begin{tabular}{llll}
\hline \hline $\begin{array}{l}\text { Influential } \\
\text { factor }\end{array}$ & Findings & Ref. \\
\hline $\begin{array}{l}\text { tagatose sweeteners } \\
\text { Processing }\end{array}$ & $\begin{array}{l}\text { White chocolate products with stevia } \\
\text { and sucralose sweeteners can prevent } \\
\text { lower fat blooms if the stevia sweetener } \\
\text { content is equal to or greater than the } \\
\text { sucralose sweetener content }\end{array}$ & {$[32]$} \\
\hline $\begin{array}{l}\text { Processing } \\
\text { treatment }\end{array}$ & $\begin{array}{l}\text { Re-tempering chocolate products can } \\
\text { increase fat bloom resistance }\end{array}$ & {$[34]$} \\
\hline $\begin{array}{l}\text { Processing } \\
\text { treatment }\end{array}$ & $\begin{array}{l}\text { Without tempering chocolate products, } \\
\text { blooming can occur on the 25th day of }\end{array}$ & {$[44]$} \\
storage & \\
\hline $\begin{array}{l}\text { Processing } \\
\text { treatment }\end{array}$ & $\begin{array}{l}\text { Insufficient tempering time and space } \\
\text { for phase separation (particles and fat) } \\
\text { resulted in the formation of blooms in } \\
\text { chocolate }\end{array}$ & {$[35]$} \\
\hline $\begin{array}{l}\text { Chocolate } \\
\text { storage } \\
\text { conditions }\end{array}$ & $\begin{array}{l}\text { When chocolate is stored at 20-32 }{ }^{\circ} \mathrm{C}, \text { it } \\
\text { can bloom }\end{array}$ & {$[36]$} \\
\hline $\begin{array}{l}\text { Chocolate } \\
\text { storage } \\
\text { conditions }\end{array}$ & $\begin{array}{l}\text { Blooming was observed on the first day } \\
\text { of storage at } 35^{\circ} \mathrm{C} . \text { However, after seven } \\
\text { days, the sensory quality of chocolate } \\
\text { had deteriorated }\end{array}$ & {$[37]$} \\
\hline $\begin{array}{l}\text { Chocolate } \\
\text { storage } \\
\text { conditions }\end{array}$ & $\begin{array}{l}12^{\circ} \mathrm{C} \text { is the optimal temperature for } \\
\text { storing chocolate products during their } \\
\text { storage period }\end{array}$ & {$[38]$} \\
\hline & & \\
\hline
\end{tabular}

\section{CONCLUSION}

Chocolate blooms can be studied and modified to make chocolate products more resistant to blooming and improve market quality. Chocolate particle size, fat content, processing treatment, and storage temperature conditions must all be considered. The smaller the particle size of the chocolate, the slower the fat bloom grows. The chocolate produced with cocoa butter alternatives such as coconut oil, palm oil, mango kernel fat, tea tree oil, and milk fat shows high resistance to fat bloom. Treatments used during the chocolate manufacturing process can affect the formation of blooms in the chocolate. Blooming can be accelerated if the chocolate is not tempered correctly. Sugar and sweeteners can slow blooming in chocolate. Additionally, re-tempering treatment can improve chocolate products' resistance to fat bloom. The optimal storage temperature for chocolate is cold to ensure that it does not bloom.

\section{ACKNOWLEDGEMENT}

The authors gratefully acknowledge Universitas Padjadjaran and the Indonesian Ministry of Education, Culture, Research, and Technology for their financing.

\section{REFERENCES}

[1] R. Indiarto, Y. Pranoto, U. Santoso, and . S., "Evaluation of Physicochemical Properties and Antioxidant Activity of Polyphenol-Rich Cacao Bean Extract Through Water Blanching," Pakistan J. Nutr., 
Rossi Indiarto et al., International Journal of Emerging Trends in Engineering Research, 9(8), August 2021, 1156 - 1161

vol. 18, no. 3, pp. 278-287, 2019, doi: 10.3923/pjn.2019.278.287.

[2] R. Indiarto, Y. Pranoto, U. Santoso, and Supriyanto, "In vitro antioxidant activity and profile of polyphenol compounds extracts and their fractions on cacao beans," Pakistan J. Biol. Sci., vol. 22, no. 1, pp. 34-44, 2019, doi: $10.3923 /$ pjbs.2019.34.44.

[3] D. L. Katz, K. Doughty, and A. Ali, "Cocoa and chocolate in human health and disease," Antioxidants Redox Signal., vol. 15, no. 10, pp. 2779-2811, 2011, doi: 10.1089/ars.2010.3697.

[4] R. Indiarto, E. Subroto, and N. Sukri, "The Chocolate Conching Technique and Its Impact on Physicochemical Properties: A Mini-Review," Int. J. Emerg. Trends Eng. Res., vol. 9, no. 6, pp. 785-790, 2021, doi: 10.30534/ijeter/2021/25962021.

[5] A. C. Aprotosoaie, S. V. Luca, and A. Miron, "Flavor Chemistry of Cocoa and Cocoa Products-An Overview," Compr. Rev. Food Sci. Food Saf., vol. 15, no. 1, pp. 73-91, 2016, doi: 10.1111/1541-4337.12180.

[6] R. P. Limbardo, H. Santoso, and J. R. Witono, "The effect of coconut oil and palm oil as substituted oils to cocoa butter on chocolate bar texture and melting point," AIP Conf. Proc., vol. 1840, 2017, doi: 10.1063/1.4982281.

[7] M. Lipp and E. Anklam, "Review of cocoa butter and alternative fats for use in chocolate - Part A. Compositional data," Food Chem., vol. 62, no. 1, pp. 73-97, 1998, doi: 10.1016/S0308-8146(97)00160-X.

[8] S. M. Hodge and D. Rousseau, "Fat bloom formation and characterization in milk chocolate observed by atomic force microscopy," JAOCS, J. Am. Oil Chem. Soc., vol. 79, no. 11, pp. 1115-1121, 2002, doi: 10.1007/s11746-002-0613-4.

[9] P. Lonchampt and R. W. Hartel, "Fat bloom in chocolate and compound coatings," European Journal of Lipid Science and Technology, vol. 106, no. 4. pp. 241-274, 2004, doi: 10.1002/ejlt.200400938.

[10] E. O. Afoakwa, A. Paterson, M. Fowler, and J. Vieira, "Fat bloom development and structure-appearance relationships during storage of under-tempered dark chocolates," J. Food Eng., vol. 91, no. 4, pp. 571-581, 2009, doi: 10.1016/j.jfoodeng.2008.10.011.

[11] Y. Kinta and T. Hatta, "Morphology of Chocolate Fat Bloom," in Cocoa Butter and Related Compounds, Elsevier, 2012, pp. 195-212.

[12] S. Sonwai and D. Rousseau, "Controlling fat bloom formation in chocolate - Impact of milk fat on microstructure and fat phase crystallisation," Food Chem., vol. 119, no. 1, pp. 286-297, 2010, doi: 10.1016/j.foodchem.2009.06.031.

[13] C. Delbaere, D. Van de Walle, F. Depypere, X. Gellynck, and K. Dewettinck, "Relationship between chocolate microstructure, oil migration, and fat bloom in filled chocolates," European Journal of Lipid Science and Technology, vol. 118, no. 12. pp. 1800-1826, 2016, doi: 10.1002/ejlt.201600164.
[14] H. Zhao, G. Bingol, and B. J. James, "Influence of non-fat particulate network on fat bloom development in a model chocolate," J. Food Eng., vol. 225, pp. 12-17, 2018, doi: 10.1016/j.jfoodeng.2018.01.006.

[15] V. Briones and J. M. Aguilera, "Image analysis of changes in surface color of chocolate," Food Res. Int., vol. 38, no. 1, pp. 87-94, 2005, doi: 10.1016/j.foodres.2004.09.002.

[16] D. Rousseau and P. Smith, "Microstructure of fat bloom development in plain and filled chocolate confections," Soft Matter, vol. 4, no. 8, pp. 1706-1712, 2008, doi: $10.1039 / \mathrm{b} 718066 \mathrm{~g}$.

[17] H. Dahlenborg, A. Millqvist-Fureby, and B. Bergenståhl, "Effect of particle size in chocolate shell on oil migration and fat bloom development," J. Food Eng., vol. 146, pp. 172-181, 2015, doi: 10.1016/j.jfoodeng.2014.09.008.

[18] T. L. T. da Silva, R. Grimaldi, and L. A. G. Gonçalves, "Temperature, time and fat composition effect on fat bloom formation in dark chocolate," Food Struct., vol. 14, pp. 68-75, 2017, doi: 10.1016/j.foostr.2017.06.006.

[19] H. S. adiah Abdul Halim, J. Selamat, S. H. Mirhosseini, and N. Hussain, "Sensory preference and bloom stability of chocolate containing cocoa butter substitute from coconut oil," J. Saudi Soc. Agric. Sci., vol. 18, no. 4, pp. 443-448, 2019, doi: 10.1016/j.jssas.2018.02.005.

[20] F. Wang, Y. Liu, L. Shan, Q. Jin, X. Wang, and L. Li, "Blooming in cocoa butter substitutes based compound chocolate: Investigations on composition, morphology and melting behavior," JAOCS, J. Am. Oil Chem. Soc., vol. 87, no. 10, pp. 1137-1143, 2010, doi: 10.1007/s11746-010-1604-z.

[21] M. Lipp et al., "Composition of genuine cocoa butter and cocoa butter equivalents," J. Food Compos. Anal., vol. 14, no. 4, pp. 399-408, 2001, doi: 10.1006/jfca.2000.0984.

[22] S. Zarringhalami, M. A. Sahari, M. Barzegar, and Z. Hamidi-Esfehani, "Enzymatically modified tea seed oil as cocoa butter replacer in dark chocolate," Int. J. Food Sci. Technol., vol. 45, no. 3, pp. 540-545, 2010, doi: 10.1111/j.1365-2621.2009.02162.x.

[23] J. Babić, D. Šubarić, Đ. Ačkar, S. Škrabal, B. Miličević, and A. Jozinović, "Effect of Different Storage Conditions on Fat Bloom Formation in Different Types of Chocolate," Hrana u Zdr. i Boles. Znan. časopis za Nutr. i dijetetiku, vol. 8, no. 2, pp. 97-104, 2019.

[24] A. Frazier and R. W. Hartel, "Bloom on chocolate chips baked in cookies," Food Res. Int., vol. 48, no. 2, pp. 380-386, 2012, doi: 10.1016/j.foodres.2012.05.011.

[25] C. K. Rosales, S. Suwonsichon, and U. Klinkesorn, "Ability of crystal promoters to delay fat bloom development in heat-resistant compound chocolate with or without the presence of crystal inhibitor," Int. J. Food Sci. Technol., vol. 52, no. 11, pp. 2343-2351, 2017, doi: 10.1111/ijfs. 13517.

[26] M. H. M. Buscato et al., "Delaying fat bloom formation in dark chocolate by adding sorbitan monostearate or 
Rossi Indiarto et al., International Journal of Emerging Trends in Engineering Research, 9(8), August 2021, 1156 - 1161

cocoa butter stearin," Food Chem., vol. 256, no. February, pp. 390-396, 2018, doi: 10.1016/j.foodchem.2018.02.127.

[27] J. R. Galdámez, K. Szlachetka, J. L. Duda, and G. R. Ziegler, "Oil migration in chocolate: A case of non-Fickian diffusion," J. Food Eng., vol. 92, no. 3, pp. 261-268, 2009, doi: 10.1016/j.jfoodeng.2008.11.003.

[28] N. De Clercq, F. Depypere, C. Delbaere, I. Nopens, H. Bernaert, and K. Dewettinck, "Influence of cocoa butter diacylglycerols on migration induced fat bloom in filled chocolates," Eur. J. Lipid Sci. Technol., vol. 116, no. 10, pp. 1388-1399, 2014, doi: 10.1002/ejlt.201300476.

[29] L. Svanberg, L. Ahrné, N. Lorén, and E. Windhab, "Impact of pre-crystallization process on structure and product properties in dark chocolate," J. Food Eng., vol. 114, no. 1, pp. 90-98, 2013, doi: 10.1016/j.jfoodeng.2012.06.016.

[30] J. Jin and R. W. Hartel, "Accelerated Fat Bloom in Chocolate Model Systems: Replacement of Cocoa Powder with Sugar Particles and the Effects of Lecithin," JAOCS, J. Am. Oil Chem. Soc., vol. 97, no. 4, pp. 377-388, 2020, doi: 10.1002/aocs. 12345.

[31] Y. J. Son et al., "Anti-blooming effect of maltitol and tagatose as sugar substitutes for chocolate making," LWT - Food Sci. Technol., vol. 88, pp. 87-94, 2018, doi: 10.1016/j.lwt.2017.09.018.

[32] L. T. Rodriguez Furlán, Y. Baracco, J. Lecot, N. Zaritzky, and M. E. Campderrós, "Effect of sweetener combination and storage temperature on physicochemical properties of sucrose free white chocolate," Food Chem., vol. 229, pp. 610-620, 2017, doi: 10.1016/j.foodchem.2017.03.002.

[33] S. Nöbel, B. Böhme, Y. Schneider, and H. Rohm, "Technofunctional barrier layers for preventing fat bloom in triple-shot pralines," Food Res. Int., vol. 42, no. $1, \quad$ pp. 69-75, 2009, doi: 10.1016/j.foodres.2008.08.011.

[34] L. Machálková, L. Hřivna, A. Ruban, E. Sapáková, and V. Rumíšková, "Effect of recipe and production technology of chocolate products on their quality during storage," Acta Univ. Agric. Silvic. Mendelianae Brun., vol. 65, no. 1, pp. 91-98, Feb. 2017, doi: 10.11118/actaun201765010091.

[35] Y. Kinta and R. W. Hartel, "Bloom formation on poorly-tempered chocolate and effects of seed addition," JAOCS, J. Am. Oil Chem. Soc., vol. 87, no. 1, pp. 19-27, 2010, doi: 10.1007/s11746-009-1473-5.

[36] H. Zhao and B. J. James, "Fat bloom formation on model chocolate stored under steady and cycling temperatures," J. Food Eng., vol. 249, pp. 9-14, 2019, doi: 10.1016/j.jfoodeng.2018.12.008.

[37] L. T. T. Bui and R. Coad, "Military ration chocolate: The effect of simulated tropical storage on sensory quality, structure and bloom formation," Food Chem., vol. 160, pp. 365-370, 2014, doi: 10.1016/j.foodchem.2014.03.084.

[38] L. Machálková, L. Hřivna, Š. Nedomová, and M. Jůzl,
"The effect of storage temperature on the quality and formation of blooming defects in chocolate confectionery," in Potravinarstvo, 2015, vol. 9, no. 1, pp. 39-47, doi: 10.5219/425.

[39] E. O. Afoakwa, A. Paterson, M. Fowler, and J. Vieira, "Microstructure and mechanical properties related to particle size distribution and composition in dark chocolate," Int. J. Food Sci. Technol., vol. 44, no. 1, pp. 111-119, 2009, doi: 10.1111/j.1365-2621.2007.01677.x.

[40] F. Wang, Y. Liu, L. Shan, Q. Jin, Z. Meng, and X. Wang, "Effect of fat composition on texture and bloom of lauric compound chocolate," Eur. J. Lipid Sci. Technol., vol. 112, no. 11, pp. 1270-1276, 2010, doi: 10.1002/ejlt.201000339.

[41] A. Bahari and C. C. Akoh, "Texture, rheology and fat bloom study of 'chocolates' made from cocoa butter equivalent synthesized from illipe butter and palm mid-fraction," Lwt, vol. 97, pp. 349-354, 2018, doi: 10.1016/j.lwt.2018.07.013.

[42] J. Jin, Q. Jin, X. Wang, and C. C. Akoh, "Improving heat and fat bloom stabilities of 'dark chocolates' by addition of mango kernel fat-based chocolate fats," $J$. Food Eng., vol. 246, no. July 2018, pp. 33-41, 2019, doi: 10.1016/j.jfoodeng.2018.10.027.

[43] R. F. Gatti, F. B. de Santana, R. J. Poppi, and D. S. Ferreira, "Portable NIR spectrometer for quick identification of fat bloom in chocolates," Food Chem., vol. 342, no. May, p. 128267, 2021, doi: 10.1016/j.foodchem.2020.128267.

[44] H. Zhao, A. K. Young, and B. J. James, "Effects of Fat Polymorphic Transformation and Nonfat Particle Size Distribution on the Surface Changes of Untempered Model Chocolate, Based on Solid Cocoa Mass," J. Food Sci., vol. 83, no. 4, pp. 998-1004, 2018, doi: 10.1111/1750-3841.14108. 